\title{
PERBEDAAN NILAI KELELAHAN ANAEROBIK ATLET SEPAKBOLA YANG DIBERIKAN BUAH SEMANGKA MERAH DAN TIDAK DIBERIKAN BUAH SEMANGKA MERAH (Citrullus lanatus)
}

\author{
Uswatun hasanah, Deny Yudi Fitranti ${ }^{*}$ \\ Program Studi Ilmu Gizi Fakultas Kedokteran Universitas Diponegoro \\ Jl.Dr.Sutomo No.18, Semarang, Telp (024) 8453708, Email : gizifk@undip.ac.id
}

\begin{abstract}
Background : Anaerobic fatigue occurs due to high-intensity activity which need energy in a short time. Anaerobic fatigue that constantly occurs may decrease athlete's performance. Watermelon is one of the fruits that contain citrulline which can help delay anaerobic fatigue.

Objective : To analyze the difference of anaerobic fatigue value on football athletes which given with and not given with red watermelon fruit.

Methods : This study was a quasi experiment with post test only control group design. Subjects for this study were 20 male athletes (15-18 years old range) who met inclusion criteria, subjects were divided into two groups, control group and treatment group. Control group was given with placebo of sugar-free syrup and treatment group was given with red watermelon fruit with a dose of 72 grams. Watermelon was given 60 minutes before conducting the Wingate test. The anaerobic fatigue measurement using Wingate test expressed in Anaerobic fatigue (AF).

Results : Subject characteristics had no differences including age and nutritional status ( $p>0.05)$, but there was a difference in body fat percent ( $p<0.05)$. Most of the subjects had normal nutritional status and good body fat percent. There were no differences in breakfast intake average of energy, fat, carbohydrates, and protein ( $p>0.05)$. Based on Independent- $t$ test, there was a difference in anaerobic fatigue value on treatment group (80.04\%) compared to control group $(82.71 \%)$.
\end{abstract}

Conclusion : There was a difference in anaerobic fatigue value on football athletes who was given with red watermelon fruit and not given with red watermelon fruit.

Keywords : Red watermelon, Wingate test, Anaerobic Fatigue ( $A F$ )

\section{ABSTRAK}

Latar Belakang: Kelelahan pada aktivitas anaerobik terjadi karena aktivitas dengan intensitas tinggi yang membutuhkan energi cepat dalam waktu yang singkat. Jika kelelahan terjadi pada atlet terus menerus maka performa atlet dapat menurun. Buah semangka merupakan salah satu buah yang banyak mengandung zat sitrulin yang dapat membantu menunda kelelahan pada aktivitas anaerobik.

Tujuan : Penelitian ini bertujuan untuk mengetahui perbedaan nilai kelelahan anaerobik atlet sepakbola yang diberikan buah semangka merah dan yang tidak diberikan buah semangka merah.

Metode: Penelitian ini merupakan penelitian quasi experiment dengan rancangan post test only with control group design. Subjek penelitian adalah 20 orang atlet laki-laki usia 15-18 tahun yang memenuhi kriteria inklusi, dibagi menjadi 2 kelompok, kelompok kontrol dan kelompok perlakuan. Kelompok kontrol diberikan plasebo berupa sirup bebas gula dan kelompok perlakuan diberikan buah semangka dengan dosis 72 gram. Buah semangka diberikan 60 menit sebelum tes dilakukan. Pengukuran kelelahan anaerobik menggunakan tes Wingate dinyatakan dalam nilai Anaerobic Fatigue (AF).

Hasil: Pada karakteristik subjek tidak ada perbedaan umur dan status gizi $(p>0,05)$ namun terdapat perbedaan persen lemak tubuh (p<0,05). Sebagian besar subjek memiliki status gizi normal dan persen lemak tubuh baik. Pada asupan sarapan pagi tidak ada perbedaan rerata asupan energi, lemak, karbohidrat, dan protein sarapan (p>0,05). Berdasarkan uji Independent-t, terdapat perbedaan nilai kelelahan anaerobik pada kelompok perlakuan yaitu sebesar $80,04 \%$ sedangkan pada kelompok kontrol sebesar $82,71 \%$.

Kesimpulan: Terdapat perbedaan nilai kelelahan anaerobik atlet sepakbola yang diberikan buah semangka merah dan yang tidak diberikan buah semangka merah.

Kata kunci: Semangka, Tes Wingate, Kelelahan Anaerobik

\section{PENDAHULUAN}

Kelelahan merupakan masalah yang sering dialami oleh atlet Indonesia dalam suatu pertandingan. Atlet cepat merasa lelah sehingga mempengaruhi daya tahan fisiknya di lapangan. ${ }^{1}$ Jika kelelahan terjadi pada atlet terus menerus maka atlet tidak dapat berkonsentrasi dan performa atlet dapat menurun. ${ }^{4}$ Indikator penurunan performa ditentukan oleh kemampuan kontraksi otot yang menghasilkan kekuatan otot. ${ }^{3}$ Kelelahan juga dapat menyebabkan dehidrasi pada atlet karena atlet terlalu banyak mengeluarkan keringat. ${ }^{4}$ 
Kelelahan pada aktivitas anaerobik terjadi karena aktivitas dengan intensitas tinggi yang membutuhkan energi cepat dalam waktu yang singkat. ${ }^{5,6,7}$ Sepakbola merupakan salah satu cabang olahraga yang membutuhkan gerakan-gerakan yang mengandung unsur kecepatan dan kekuatan otot yang melibatkan otot-otot kaki yang bisa mengalami perubahan setiap 5-6 detik dan perubahan kecepatan lari sebanyak 40-60x. Gerakan-gerakan atau aktivitas seperti melompat, mengoper, melempar bola, menendang bola, ataupun mengejar bola dengan cepat bersifat anaerobik dan dapat menyebabkan kelelahan anaerobik. $^{8}$ Akumulasi asam laktat dapat menyebabkan kelelahan anaerobik yang timbul ketika olahraga sedang berlangsung. ${ }^{11}$ Asam laktat yang terdapat di sel otot menyebabkan asidosis laktat sehingga neuromuscular junction tidak dapat meneruskan rangsangan-rangsangan persyarafan ke serabut-serabut otot maka otot tidak mampu berkontraksi. ${ }^{12}$

Kelelahan anaerobik dapat dikurangi dengan mengkonsumsi buah semangka, karena buah semangka memiliki kandungan sitrulin. Sitrulin merupakan golongan asam amino non esensial yang paling banyak terkandung dalam buah semangka yaitu sebesar $160 \mathrm{mg}$ sitrulin dalam 100 gr buah semangka. ${ }^{9}, 10$ Pemberian sitrulin sebelum latihan dapat menunda kelelahan anaerobik yang dialami atlet karena sitrulin mampu mengurangi penumpukan atau akumulasi asam laktat yang merupakan produk sampingan dari proses glikolisis anaerobik..$^{5,6,10}$ Sitrulin mempercepat penguraian laktat di otot sehingga laktat dapat dimetabolisme kembali di hati dan ginjal untuk membentuk energi melalui siklus cory. Sitrulin juga mampu mendetoksifikasizat amonia yang merupakan salah satu komponen siklus urea di dalam hati bersama dengan asam amino lainnya seperti arginin dan ornitin. Zat amonia dalam darah adalah produk yang terakumulasi di otot saat Adenosine Monophospat (AMP) terdeaminasi selama pembentukan Adenosine Triphospat (ATP). Amonia akan mengaktifkan fosfofruktokinase yang membantu produksi laktat. Karena kadar amonia meningkat maka kadar laktat juga akan mengalami peningkatan sehingga terjadi kelelahan. ${ }^{9,14}$

Beberapa studi telah dilakukan untuk mengetahui pengaruh pemberian sitrulin dalam sediaan berupa jus maupun tablet sitrulin terhadap kelelahan anaerobik baik pada manusia dan pada hewan coba. Penelitian yang dilakukan di Spanyol pada Tahun 2013, menggunakan buah semangka sebagai jus sebanyak $500 \mathrm{ml}$ dengan kandungan sitrulin yang diketahui sebesar 1,17 gram sebelum latihan mampu mengurangi kelelahan anaerobik pada atlet sebesar 13-18\%. ${ }^{10,15,16}$ Penelitian lainnya yang dilakukan pada tikus coba yang diberikan suplementasi tablet sitrulin sebelum latihan sebanyak $250 \mathrm{mg}$ selama 7 hari, dapat menekan akumulasi kadar amonia dalam darah dan menunda agar kelelahan tidak cepat terjadi. ${ }^{9,17}$

Penelitian ini bertujuan mengetahui perbedaan nilai kelelahan anaerobik atlet sepakbola yang diberikan buah semangka merah dan tidak diberikan buah semangka merah. Hasil penelitian ini diharapkan dapat memberikan informasi bagi atlet dan pelatih tentang pengaruh pemberian buah semangka merah terhadap kelelahan otot kaki pada atlet sepakbola.

\section{METODE}

Penelitian dilakukan di Pusat Pelatihan Pelajar (PPLP) Jawa Tengah pada bulan Oktober 2014. Penelitian ini merupakan penelitian quasi experiment dengan rancangan randomized post test control group design dan termasuk dalam ruang lingkup gizi olahraga. Subjek penelitian ini adalah atlet sepak bola dengan kriteria inklusi berusia 15 18 tahun yang berada di Pusat Pelatihan Pelajar (PPLP) Jawa Tengah, tidak sedang dalam perawatan dokter atau pascaoperasi 6 bulan sebelum penelitian, tidak sedang mengalami cedera, tidak mengkonsumsi minuman elektrolit, sport drink, dan minuman berenergi yang berfungsi sebagai pembangkit tenaga sebelum dan selama penelitian berlangsung, tidak melakukan aktivitas yang dapat menyebabkan kelelahan sebelum tes dilakukan, serta bersedia mengikuti penelitian melalui persetujuan Informed Consent. Penelitian ini telah mendapat izin ethical clearence dari Fakultas Kedokteran Universitas Diponegoro.

Berdasarkan perhitungan, subjek minimal yang diperlukan adalah 9 orang tiap kelompok dengan antisipasi drop out sebesar $10 \%$ menjadi 10 orang untuk tiap kelompok. Jumlah tersebut ditentukan dengan menggunakan rumus perkiraan besar sampel dua kelompok independen. Pengambilan subjek menggunakan teknik total sampling. Subjek dibagi menjadi 2 kelompok, yaitu kelompok perlakuan dan kelompok kontrol sehingga diperoleh masing-masing 10 subjek pada setiap kelompok.

Variabel bebas pada penelitian ini adalah pemberian buah semangka merah (Citrullus Lanatus). Kelompok perlakuan mendapatkan buah semangka merah masing-masing sebanyak 72 gram dengan kandungan sitrulin 1,17 gram dan kelompok kontrol mendapatkan plasebo berupa sirup bebas gula masing-masing sebanyak $250 \mathrm{ml}$. Buah 
semangka dan sirup merah bebas gula diberikan 60 menit sebelum melakukan tes Wingate. Variabel terikat pada penelitian ini adalah kelelahan anaerobik. Kelelahan anaerobik diukur menggunakan tes Wingate selama 30 detik. Tes Wingate merupakan tes yang dapat menggambarkan nilai kelelahan anaerobik subjek dengan mengayuh sepeda statis selama 30 detik kemudian dihitung revolusi atau perputaran roda dalam interval 5 detik. Setelah melakukan tes Wingate, data yang telah diperoleh dihitung menggunakan rumus baku yang telah ditetapkan untuk memperoleh nilai kelelahan anaerobik yaitu dengan membandingkan antara nilai Peak Power Output (PP) tertinggi dan terendah yang dinyatakan dalam persen. Bila persentase kelelahan anaerobik $\geq 50 \%$ maka termasuk kategori lelah sedangkan bila persentase kelelahan anaerobik $<50 \%$ maka termasuk kategori tidak lelah. ${ }^{18}$ Pengecekan kelelahan otot ini dilaksanakan 60 menit setelah pemberian buah semangka dan sirup bebas gula.

Data yang dikumpulkan meliputi data berat badan, tinggi badan, persen lemak tubuh dan gambaran asupan sarapan pagi. Pengukuran berat badan diperoleh melalui penimbangan menggunakan timbangan injak digital dengan ketelitian $0,1 \mathrm{~kg}$. Pengukuran tinggi badan dilakukan dengan menggunakan microtoise dengan batas ukur $200 \mathrm{~cm}$ dan ketelitian $0,1 \mathrm{~cm}$. Pengukuran berat badan dan tinggi badan dilakukan untuk mengetahui indeks massa tubuh dan menetapkan status gizi atlet.

Tabel. 1 kategori status gizi menurut $\mathrm{WHO}^{32}$

\begin{tabular}{cc} 
Tabel. 1 kategori status gizi menurut & WHO \\
\hline Kategori & Status Gizi \\
\hline Underweight & $<18,5 \mathrm{~kg} / \mathrm{m}^{2}$ \\
Normal & $18,5-22,9 \mathrm{~kg} / \mathrm{m}^{2}$ \\
Overweight & $23-24,9 \mathrm{~kg} / \mathrm{m}^{2}$ \\
Obesitas & $>25 \mathrm{~kg} / \mathrm{m}^{2}$ \\
\hline
\end{tabular}

Persentase lemak tubuh diukur menggunakan

Bioelectric Impedance Analyzer (BIA) injak.

Tabel. 2 kategori persen lemak tubuh atlet laki-laki ${ }^{24}$

\begin{tabular}{cc}
\hline Kategori & Persen lemak tubuh (\%) \\
\hline Sangat baik & $6-10 \%$ \\
Baik & $11-14 \%$ \\
Cukup & $15-20 \%$ \\
Overweight & $21-24 \%$ \\
Obesitas & $25-30 \%$ \\
\hline
\end{tabular}

Subjek mengkonsumsi sarapan pada pukul 06.00 pagi sebelum tes Wingate dilakukan. Gambaran asupan sarapan didapat dengan formulir recall, kemudian data asupan sarapan yang terkumpul dianalisis menggunakan program nutrisurvey. Energi yang dibutuhkan saat sarapan pagi yaitu sekitar $30 \%$ dari kebutuhan energi sehari. Bila asupan energi sarapan $<30 \%$ maka termasuk kategori kurang sedangkan bila asupan energi sarapan $\geq 30 \%$ maka termasuk kategori baik.

Analisis data dilakukan dengan menggunakan program SPSS for Windows. Analisis univariate dan bivariate diawali dengan uji kenormalan data dengan uji Shapiro-Wilk. Uji Mann Whitney dilakukan untuk melihat perbedaan usia, status gizi dan asupan karbohidrat saat sarapan antara kelompok perlakuan dan kelompok kontrol. Independent $t$ test dilakukan untuk melihat perbedaan persen lemak tubuh, asupan energi, lemak, protein saat sarapan, dan Anaerobic Fatigue (AF) antara kelompok perlakuan dan kelompok kontrol $(\mathrm{p}<0,05)$.

\section{HASIL PENELITIAN Karakteristik Subjek}

Karakteristik subjek terdiri dari gambaran usia, status gizi dan persen lemak tubuh disajikan dalam Tabel 3. Subjek adalah atlet sepakbola berusia 15-18 tahun sebanyak 20 orang. 
Tabel 3. Karakteristik Subjek Penelitia

\begin{tabular}{|c|c|c|c|c|c|c|c|}
\hline \multirow[t]{2}{*}{ Karakteristik subjek } & \multirow[t]{2}{*}{ rerata $\pm \mathrm{SD}$} & \multicolumn{2}{|c|}{$\begin{array}{l}\text { Perlakuan } \\
(\mathrm{n}=10)\end{array}$} & \multirow[t]{2}{*}{ rerata \pm SD } & \multicolumn{2}{|c|}{$\begin{array}{c}\text { Kontrol } \\
(\mathrm{n}=10)\end{array}$} & \multirow[t]{2}{*}{$\mathrm{P}$} \\
\hline & & $\mathrm{n}$ & $\%$ & & $\mathrm{n}$ & $\%$ & \\
\hline $\begin{array}{l}\text { Umur } \\
15-18 \text { tahun }\end{array}$ & $15,9 \pm 0,737$ & - & - & $16,10 \pm 0,875$ & - & - & $0,574 *$ \\
\hline $\begin{array}{l}\text { Status Gizi } \\
\text { Underweight }\left(<18,5 \mathrm{~kg} / \mathrm{m}^{2}\right) \\
\text { Normal }\left(18,5-22,9 \mathrm{~kg} / \mathrm{m}^{2}\right) \\
\text { Overweight }\left(23-24,5 \mathrm{~kg} / \mathrm{m}^{2}\right)\end{array}$ & $20,64 \pm 1,48$ & $\begin{array}{l}1 \\
9 \\
-\end{array}$ & $\begin{array}{c}10 \% \\
90 \% \\
- \\
\end{array}$ & $21,73 \pm 1,70$ & $\begin{array}{l}1 \\
7 \\
2 \\
\end{array}$ & $\begin{array}{l}10 \% \\
70 \% \\
20 \% \\
\end{array}$ & $0,070 *$ \\
\hline $\begin{array}{l}\text { Persen lemak tubuh }(\%) \\
\text { Sangat baik }(6-10 \%) \\
\text { Baik }(11-14 \%) \\
\text { Cukup }(15-20 \%)\end{array}$ & $10,71 \pm 2,41$ & $\begin{array}{l}6 \\
3 \\
1\end{array}$ & $\begin{array}{l}60 \% \\
30 \% \\
10 \%\end{array}$ & $13,90 \pm 3,49$ & $\begin{array}{l}2 \\
5 \\
3\end{array}$ & $\begin{array}{l}20 \% \\
50 \% \\
30 \%\end{array}$ & $0,029 * *$ \\
\hline
\end{tabular}

*Mann-Whitney

** Independent $t$ test

Berdasarkan hasil analisis uji beda, menunjukkan tidak ada perbedaan usia dan Indeks Massa Tubuh antara kelompok perlakuan dan kelompok kontrol $(p>0,05)$. Namun, ada perbedaan persen lemak tubuh antara kelompok perlakuan dan kelompok kontrol $(\mathrm{p}<0,05)$.

Dari Tabel 3. terlihat bahwa subjek pada kelompok perlakuan memiliki rata-rata umur sedikit lebih muda dari kelompok kontrol. Berdasarkan kategori status gizi, pada kelompok perlakuan terdapat $10 \%$ subjek dengan status gizi underweight dan 90\% subjek dengan status gizi normal, sedangkan pada kelompok kontrol terdapat $10 \%$ subjek dengan status gizi underweight, $70 \%$ subjek dengan status gizi normal dan $20 \%$ subjek dengan status gizi overweight. Sementara itu, berdasarkan kategori persen lemak tubuh terdapat $10 \%$ subjek yang memiliki persen lemak tubuh dalam kategori cukup, 30\% subjek dalam kategori baik dan 60\% subjek dalam kategori sangat baik pada kelompok perlakuan, sedangkan pada kelompok kontrol terdapat $30 \%$ subjek dengan kategori persen lemak tubuh cukup, $50 \%$ subjek dalam kategori baik dan $20 \%$ subjek dalam kategori persen lemak tubuh sangat baik.

\section{Asupan Zat Gizi sebelum Intervensi}

Asupan zat gizi subjek kelompok kontrol dan perlakuan sebelum intervensi disajikan dalam Tabel. 4

Tabel. 4 Asupan Zat Gizi sebelum Intervensi

\begin{tabular}{|c|c|c|c|c|c|c|c|}
\hline \multirow{2}{*}{ Variabel } & \multirow{2}{*}{ rerata \pm SD } & \multicolumn{2}{|c|}{$\begin{array}{l}\text { Perlakuan } \\
(\mathrm{n}=10)\end{array}$} & & \multicolumn{2}{|c|}{$\begin{array}{c}\text { Kontrol } \\
(\mathrm{n}=10)\end{array}$} & \multirow{2}{*}{$P$} \\
\hline & & $\mathrm{n}$ & $\%$ & & $\mathrm{n}$ & $\%$ & \\
\hline \multicolumn{8}{|l|}{$\begin{array}{l}\text { Asupan energi } \\
\text { sarapan (Kkal) }\end{array}$} \\
\hline Kurang $(<30 \%)$ & $633,9 \pm 99,5$ & 9 & $90 \%$ & $610,3 \pm 62,6$ & 10 & $100 \%$ & $0,535 * *$ \\
\hline Baik $(\geq 30 \%)$ & & 1 & $10 \%$ & & - & - & \\
\hline $\begin{array}{c}\text { Asupan } \\
\text { karbohidrat } \\
\text { sarapan }(g)\end{array}$ & $81,12 \pm 13,5$ & - & - & $83,20 \pm 17,4$ & - & - & $0,940^{*}$ \\
\hline $\begin{array}{l}\text { Asupan lemak } \\
\text { sarapan }(\mathrm{g})\end{array}$ & $23,66 \pm 5,90$ & - & - & $20,21 \pm 3,21$ & - & - & $0,128 * *$ \\
\hline $\begin{array}{l}\text { Asupan protein } \\
\text { sarapan }(\mathrm{g})\end{array}$ & $23,28 \pm 3,61$ & - & - & $20,52 \pm 6,62$ & - & - & $0,527 * *$ \\
\hline
\end{tabular}

*Mann-Whitney

**Independent $t$ test

Berdasarkan uji beda dapat diinterpretasikan bahwa tidak ada perbedaan asupan energi, karbohidrat, lemak dan protein saat sarapan antara kelompok perlakuan dan kelompok kontrol $(\mathrm{p}>0.05)$.
Tabel. 4 menunjukkan bahwa, pada kelompok perlakuan terdapat $90 \%$ subjek yang memiliki asupan energi sarapan dalam kategori kurang dan $10 \%$ subjek memiliki asupan energi sarapan dalam kategori baik. Sedangkan pada 
kelompok kontrol, 100\% subjek memiliki asupan energi sarapan dalam kategori kurang. Pada kelompok perlakuan, rata-rata asupan karbohidrat sarapan lebih rendah dari kelompok kontrol. Sedangkan rata-rata asupan lemak dan protein sarapan pada kelompok perlakuan lebih besar dari kelompok kontrol.

\section{Perbedaan nilai kelelahan anaerobik / Anaerobic Fatigue (AF) setelah Intervensi}

Nilai kelelahan anaerobik diperoleh dari selisih antara Peak Power Output (PP) tertinggi dan terendah yang dinyatakan dalam persen. Dikatakan masuk kategori lelah bila $\mathrm{AF} \geq 50 \%$ dan dikatakan tidak lelah bila $\mathrm{AF}<50 \%$.

\begin{tabular}{ccc}
\multicolumn{3}{c}{ Tabel.5 Kategori Anaerobic Fatigue $(\mathbf{A F})^{\mathbf{1 8}}$} \\
\hline Kategori AF & $\begin{array}{c}\text { Kelompok perlakuan } \\
(\mathrm{n}=10)\end{array}$ & $\begin{array}{c}\text { Kelompok kontrol } \\
(\mathrm{n}=10)\end{array}$ \\
\hline Lelah $(\geq 50 \%)$ & $100 \%$ & $100 \%$ \\
Tidak lelah $(<50 \%)$ & - & - \\
\hline
\end{tabular}

Berdasarkan kategori AF pada Tabel. 5 dapat dilihat bahwa subjek pada kelompok perlakuan dan kelompok kontrol, keduanya berada dalam kategori lelah dengan nilai $\mathrm{AF} \geq 50 \%$.
Kemudian dilakukan uji beda untuk mengetahui perbedaan nilai kelelahan anaerobik setelah pemberian buah semangka merah pada kelompok perlakuan dan kelompok kontrol.

Tabel. 6 Perbedaan nilai kelelahan anaaerobik setelah intervensi

\begin{tabular}{cccc}
\hline Variabel & $\begin{array}{c}\text { Perlakuan } \\
(\mathrm{n}=10)\end{array}$ & $\begin{array}{c}\text { Kontrol } \\
(\mathrm{n}=10)\end{array}$ & $\mathrm{p}$ \\
\cline { 2 - 4 } & Mean $\pm \mathrm{SD}$ & Mean \pm SD & \\
\hline $\begin{array}{c}\text { Kelelahan } \\
\text { anaerobik }\end{array}$ & $80,04 \pm 2,07 \%$ & $82,71 \pm 2,10 \%$ & $0,011^{*}$ \\
\hline Independent t test & & &
\end{tabular}

Pada Tabel. 6 berdasarkan uji statistik, terdapat perbedaan nilai kelelahan anaerobik antara kelompok perlakuan dan kelompok kontrol setelah pemberian buah semangka merah sebelum latihan $(\mathrm{p}<0,05)$. Pada kelompok perlakuan memiliki kelelahan anaerobik sebesar $80,04 \%$. Nilai ini lebih rendah dibanding kelelahan anaerobik pada kelompok kontrol yaitu sebesar $82,1 \%$.

\section{PEMBAHASAN}

\section{Karakteristik Subjek}

Subjek pada penelitian ini adalah 20 orang atlet sepakbola yang terbagi dalam dua kelompok. Subjek penelitian ini berusia 15-18 tahun. Pada usia remaja akan terjadi peningkatan kekuatan otot sebesar 5-10\%. Pada usia remaja cadangan tenaga dan kekuatan fisik lebih besar dibanding usia lebih tua. Kekuatan dan massa otot akan menurun seiring dengan pertambahan usia. ${ }^{19}$ Hasil analisis uji beda menunjukkan tidak ada perbedaan umur dan status gizi pada kelompok perlakuan dan kelompok kontrol. Berdasarkan kategori status gizi, sebagian besar subjek memiliki status gizi normal. Status gizi normal diperlukan untuk membantu pertumbuhan remaja guna mewujudkan prestasi optimal karena itu atlet membutuhkan bentuk tubuh ideal dengan status gizi normal. Apabila status gizi atlet underweight dapat mengakibatkan atlet mengalami kurang gizi, sementara apabila status gizi atlet overweight akan menyebabkan simpanan lemak berlebih dalam tubuh. ${ }^{21}$

Hasil analisis uji beda menunjukkan terdapat perbedaan persen lemak tubuh antara kelompok kontrol dan kelompok perlakuan, dimana rata-rata persen lemak tubuh pada kelompok kontrol lebih besar dari kelompok perlakuan. Berdasarkan kategori persen lemak tubuh, sebagian besar subjek memiliki persen lemak tubuh yang baik. Persen lemak tubuh yang baik dapat membantu atlet bergerak dengan lebih gesit dan lincah. Apabila persentase lemak tubuh seorang atlet berlebih, maka atlet disarankan untuk dapat mengurangi berat badan sehingga dicapai persen lemak tubuh yang ideal. ${ }^{22}$

\section{Gambaran Asupan Gizi Subjek}

Pada penelitian ini, tidak ada perbedaan asupan energi, karbohidrat, lemak dan protein sarapan antara kelompok perlakuan dan kelompok kontrol. Berdasarkan kategori kecukupan asupan energi sarapan, hampir seluruh subjek berada dalam kategori kurang. Kecukupan energi sarapan pagi yaitu sekitar 30\% dari kebutuhan energi sehari.

Asupan zat gizi subjek sebelum intervensi dapat mempengaruhi nilai kelelahan anaerobik. Asupan energi, karbohidrat, lemak dan protein dari konsumsi sarapan pagi penting untuk menunjang agar tubuh mampu melakukan aktivitas dengan baik dan diharapkan terjadi ketersediaan energi bagi 
tubuh terutama otot agar tetap dapat berkontraksi serta mencegah terjadinya kelelahan selama menjalani latihan atau pertandingan. Apabila Atlet melewatkan sarapan dan melanjutkan latihan ketahanan intensif, atlet akan mengalami kelelahan lebih awal. Hal ini dikarenakan ketika penyimpanan glikogen otot kosong, maka tubuh tidak akan memiliki glikogen yang cukup dalam hati untuk menyuplai ulang glukosa untuk darah sehingga kadar glukosa darah akan menurun. Sarapan pagi yang baik harus banyak mengandung karbohidrat karena akan merangsang glukosa dan mikro nutrient dalam otak yang dapat menghasilkan energi dan membantu menyediakan penyimpanan glikogen dalam otot. ${ }^{29}$

\section{Perbedaan Nilai Kelelahan Anaerobik atlet sepakbola setelah Intervensi}

Berdasarkan kategori AF, seluruh subjek pada kelompok perlakuan dan kelompok kontrol keduanya berada dalam kategori lelah. Hal ini kemungkinan karena asupan energi sarapan subjek yang kurang dari kecukupan. Selain itu, terdapat hubungan positif antara persentase lemak tubuh terhadap kelelahan. Jika atlet memiliki persen lemak tubuh yang berlebihan maka atlet akan cepat merasakan kelelahan karena persentase lemak dalam tubuh yang terlalu banyak membuat tubuh menjadi kesulitan untuk bergerak dengan gesit sehingga ketahanan fisik atlet akan menurun dan terjadi kelelahan.

Kelelahan anaerobik pada atlet sepakbola dapat dikurangi dengan pemberian buah semangka merah (Citrullus Lanatus). Hasil penelitian menunjukkan bahwa subjek yang diberikan semangka merah memiliki nilai kelelahan anaerobik lebih rendah dibandingkan dengan subjek yang tidak diberikan buah semangka. Hasil analisis statistik menunjukkan bahwa ada perbedaan nilai kelelahan anaerobik antara kelompok perlakuan dan kelompok kontrol.

Peran buah semangka merah dalam mengurangi kelelahan anaerobik adalah karena adanya kandungan sitrulin. Sitrulin merupakan salah satu asam amino non esensial. Kandungan sitrulin dalam buah semangka dapat mengurangi penumpukan atau akumulasi laktat yang menjadi faktor yang mempercepat terjadinya kelelahan pada otot. Akumulasi laktat ini terjadi ketika tubuh membutuhkan energi namun tubuh tidak memiliki oksigen yang cukup untuk menghasilkan energi. Energi selanjutnya akan dihasilkan melalui proses glikolisis anaerobik dimana glukosa dimetabolisme untuk menghasilkan ATP dan menghasilkan produk sisa berupa laktat. Laktat akan menurunkan $\mathrm{pH}$ darah dan otot, penurunan $\mathrm{pH}$ ini akan menghambat kerja enzim glikolitik dan mengganggu reaksi kimia didalam sel otot yang dapat menyebabkan kontraksi otot melemah dan mengalami kelelahan. Kemudian sitrulin akan menguraikan laktat di otot secara cepat sehingga laktat dapat dimetabolisme kembali di hati dan ginjal melalui siklus cory. ${ }^{5-7,11,13}$

Sitrulin juga mampu mendetoksifikasi zat amonia yang merupakan salah satu komponen siklus urea di dalam hati bersama dengan asam amino lainnya seperti arginin dan ornitin. Zat amonia dalam darah adalah produk yang terakumulasi di otot saat Adenosine Monophospat (AMP) terdeaminasi selama pembentukan Adenosine Triphospat (ATP). Amonia akan mengaktifkan fosfofruktokinase yang membantu produksi laktat. Karena kadar amonia meningkat maka kadar laktat juga akan mengalami peningkatan sehingga terjadi kelelahan. ${ }^{9,14}$

Hasil penelitian Tarazona et al menunjukkan bahwa subjek yang diberikan buah semangka sebagai jus dengan kandungan sitrulin 1,17 gram sebelum latihan memiliki kelelahan anaerobik yang lebih rendah dari kelompok yang tidak diberi jus buah semangka. ${ }^{10}$ Sedangkan hasil penelitian Lopez et al menunjukkan pemberian sitrulin dalam bentuk tablet sebanyak $6 \mathrm{gr} / \mathrm{hari}$ mengurangi akumulasi laktat dan meningkatkan performa atlet. ${ }^{15}$

\section{SIMPULAN}

Berdasarkan penelitian yang telah dilakukan, dapat disimpulkan terdapat perbedaan nilai kelelahan anaerobik pada atlet sepakbola. Atlet sepakbola yang diberikan buah semangka merah memiliki nilai kelelahan anaerobik lebih rendah dibanding yang tidak diberikan buah semangka merah.

\section{SARAN}

Perlu dilakukan penelitian lebih lanjut mengenai perbedaan nilai kelelahan anaerobik dengan pemeriksaan laboratorium kadar asam laktat darah pada manusia untuk mengetahui apakah pemberian buah semangka merah dapat mengurangi akumulasi asam laktat di otot. Selain itu, diperlukan wawancara dengan masing-masing subjek berkaitan dengan kelelahan yang dialami untuk mengurangi bias pada penelitian.

\section{DAFTAR PUSTAKA}

1. Fridintya, Galuh. Efektivitas Pemberian Jus Pisang Ambon dan Jus Pisang Raja dalam mengatasi Kelelahan Otot pada Tikus Wistar. Semarang. Fakultas Kedokteran Universitas Diponegoro. 2011 
; p:1-2. Available from: URL: http://eprints.undip.ac.id/Aranta G F G2C007010.pdf

2. Immawati, Armina. Pengaruh Pemberian Softdrink terhadap Performa dan Tes Ketrampilan pada Atlet Sepak Bola Usia 15-18 tahun. Semarang. Fakultas Kedokteran Universitas Diponegoro. 2011; p:6. Available from: URL:http://eprints.undip.ac.id/Armina Immawati.pdf

3. Giriwijoyo, Santosa. Ilmu Faal Olahraga( Fisiologi Olahraga), Fungsi Tubuh Manusia pada Olahraga untuk Kesehatan dan Prestasi. Bandung : PT Remaja Rosdakarya. 2012; p:16-17

4. Hernawati. Produksi Asam Laktat pada Exercise Aerobik dan Anaerobik. Bandung. FPMIPA Universitas Pendidikan Indonesia; p:2-3.Available from: URL : http://file.upi.edu/Hernawati.pdf

5. Widiyanto. Latihan Fisik dan Laktat. Yogyakarta. Fakultas Ilmu Kesehatan. Universitas Negeri Yogyakarta. 2003; p:8-9. Available from: URL : http://staff.uny.ac.id/penelitian/Widiyanto.LATIHAN FISIK DAN LAKTAT.pdf

6. Sumartiningsih, Sri, Sugiharto. Pemulihan Asam Laktat pada Fase Pemulihan Aktif dengan Argocycle selama 5 menit. Semarang. Universitas Negeri Semarang. 2012; p: 1-2. Available from. URL : http://journal.unnes.ac.id/nju/index.php/miki

7. Irawan, MA. Cairan, Karbohidrat dan Performa Sepak Bola. Sports Science Brief. [serial online] 2007 [dikutip 2014 Juni 25];[10 halaman]. Available from: URL: http://www.pssplab.com/iournal/07.pdf

8. Sadikin Muhammad, Ermita Ilyas, Fanny Septiani F. Kelelahan otot: Pengaruhnya pada Sediaan Otot Rangka Rana sp. Jakarta. Fakultas Kedokteran Universitas Indonesia. 2004; p:1-3 Available from. URL : http://indonesia.digitaljournals.org.

9. Silverthorn DU. Skeletal muscle. In: Berriman L, Reid AA, Dekel Z, editors. Human Physiology: An Integrated Approach. 3rd ed. San Francisco: Daryl fox publisher; 2004; p: 71-75.

10. Lubis Munar, Siska Mayasari Lubis. Asidosis Laktat. Majalah Kedokteran Nusantara volume 39. Medan. Departemen Ilmu Kesehatan Anak Fakultas Kedokteran USU. 2006; p: 1-2. Available from. URL : http://repository.usu.ac.id

11. Kohei Takeda, Masanao Machida, Akiko Kohara, Naomi Omi. Effects of Citrulline Supplementation on Fatigue and Exercise Performance in Mice. $J$ Nutr Sci Vitaminol 2011. 57, 246-250.

12. Diaz Tarazona MP, Alacid F, Carraco M, Martinez I, Aguayo E. Watermelon Juice : A Potential Functional Drink for Sore Muscle Relief in Athletes. Journal of Agricultural and Food Chemistry. 2013; p:13-16.

13. Daniel J Wilkinson, Nicholas J Smeeton, Peter W Watt. Ammonia Metabolism, The Brain and Fatigue. Journal of Neurobiology. 2010; p:13.journal homepage: www.elsevier.com/locate/pneurobio.

14. Cabral Lopez JA, Cisneros Rivera A, Camacho Rodriguez, Gonzalez Sanchez, Sanchez Serna,
Trejo M. Modification of Fatigue Indicators using Citrulline Malate for High Performance Endurance Athletes 2012; p:1-4. Available at : www.sciencediret.com.

15. Rimando Agnez M, Veazie Perkins PM. Determination of Citrulline in Watermelon Rind. Journal of Chromathography. 2005: 196-200. Available at: www.sciencedirect.com.

16. Giaanesini Benoit, Cozzone JP, Verleye Marc, Bendahan David, Yann Le fur, et al.citrulline Malate Supplementation Increases Muscle Efficiency in Rat Skeletal Muscle. European Journal of Pharmacology 667 (2011) 100-104.

17. Purnomo, JS, Hardian. Pengaruh Pemberian Tablet Asam Amino terhadap Kelelahan Otot. Semarang. Fakultas Kedokteran Universitas Diponegoro. 2010; p: 3-6. Available at : http://eprints.undip.ac.id.jeffry.pdf.

18. World Health Organization. The Asia Pasific Perspective: Redefining Obesity and Its Treatment. 2000.

19. Susilo, Eko Andi. Hubungan Persentase Lemak Tubuh Terhadap Daya Tahan Kardiorespirasi Atlet Pencak Silat. Surabaya. Fakultas Ilmu Keolahragaan. 2013; p: 4-5. Available at: http//ejournal.unesa.ac.id/jurnal-kesehatanolahraga.

20. Perdana fachrudin, Hardinsyah. Analisis Jenis, Jumlah, dan Mutu Gizi Konsumsi Sarapan. Jurnal Gizi dan Pangan. Bogor. Fakultas Ekologi Manusia. Institut Pertanian Bogor. 2013; p: 5; 3946.

21. Astran, Kaare Rodahl. Textbook Of Work Physiology. 3 th ed. United States of America:McGraw-Hill. 1986 p; 342-346;487-514

22. Arum, Virra Mayang. Hubungan Intensitas Latihan, Persen Lemak Tubuh, dan Kadar Hemoglobin dengan Ketahanan Kardiorespirasi Atlet Sepakbola. Semarang. Fakultas Kedokteran Universitas Diponegoro. 2013; p: 10-11. Available at : http://eprints.undip.ac.id/Virra Mayang Arum

23. Utoro, Bayu Febri. Pengaruh Penerapan Carbohydrate Loading Modifikasi Terhadap Kesegaran Jasmani Atlet Sepakbola. Semarang. Fakultas Kedokteran Universitas Diponegoro. 2011; p:20-21. Available at : http://eprints.undip.ac.id/Bayu_Febri_Utoro.pdf

24. Irawan MA. Nutrisi, Energi, dan Performa Olahraga. Sport Science Brief. [serial online] 2007 [dikutip 2015 Feb 5] ; [13 halaman]. Available from: URL: http://www.pssplab.com/journal/04.pdf

25. Nestle Nutrition Institute. Sports Nutrition Focus. Sarapan dan Camilan : Dua Strategi Penting Pemenuhan Kebutuhan Asupan Makanan untuk Ketahanan Atlet. 2009: p: 1-4. Available at: http://www.nestlenutrition-institute.org. 